\title{
Entrepreneurial Training Effectiveness with Special Reference to District Industrial Centre, Thiruvallur
}

\section{J. Johnson Pandian}

\begin{abstract}
Entrepreneurs can be trained to start their industrial unit or a business or a service in different field if proper inputs in the form of training are given. The existence and making of an entrepreneur depend on a conducive environment. The development of an entrepreneurship depends on human factor and environment. In India where human resource found in plenty, individual with requisite entrepreneurial skill can be identified. It was in 1950 in India that the need for the entrepreneurial development was first felt end since then a substantial amount of research has gone in to this sphere. Initially this program was run by Gujarat Industrial and Investment Corporation, and its basic elements and characteristic were crystallized through repeated experiments unit 1978, when Gujarat's financial institution and industrial, promotion agencies jointly sponsored a separate center for Entrepreneurship Development to administer the program. The center's success in turn convinced India national financial institutions that the program was relevant for in 1983 to conduct research, offer expert advice, impart knowledge and help state-level agencies in carrying out their training.
\end{abstract}

Keywords: Entrepreneur, Entrepreneurship Development, Environment.

\section{INTRODUCTION}

An entrepreneur supplies capital as a adventurer for taking risk, and screens and controls the business tasks. The entrepreneur is normally a sole owner, a person who is a pair in the business, or the person who possesses maximum shares in a company. As indicated by financial analyst Joseph Alois Schumpeter (1883-1950), entrepreneurs are not really propelled by benefit yet see it as a standard for estimating accomplishment or achievement. Schumpeter found that they significantly esteem confidence, take a stab at qualification through greatness.

\section{OBJECTIVES OF THE STUDY}

- To know about the working of DIC.

- To know about the Entrepreneurial Development Program provided by DIC, Thiruvallur.

Revised Manuscript Received on December 05, 2019.

* Correspondence Author

Dr. J. Johnson Pandian*, HOD, Department of Commerce, KCSKN College, Chennai, India. E-mail: pandian.kkdi@gmail.com
- To study about the entrepreneurial training effectiveness provided by DIC, Thiruvallur.

- To know the overall satisfaction of EDP training Program.

\section{REVIEW OF LITERATURE}

Agarwal, K. K (2009) in his examination investigated that extraordinary compared to other approach to comprehend neediness is to advance little scale enterprises. India is moving quick to rise as perhaps the most grounded economy on the planet by 2020. And yet, according to Dorothea Schmidt of the International Labor Organization (ILO) work pattern group, around $34.3 \%$ of the Indian populace are as yet living beneath the benchmark of \$1/day set by the United Nations Development Program (UNDP). It can assume a crucial job in pay conveyance, monetary self-reliance and financial inspiring. The Central just as State Governments in India are finding a way to advance emtrepreneurial exercises. One untested presumption in arrangement having is the effect of frame of mind. Demeanor development is exceptionally impacted by the family foundation of a person just as his/her instructive foundation. Thus, this paper estimates that a person's family foundation and instructive capability impacts his/her mentality towards business people and enterprise. This theory was tried on in excess of 100 respondents in Varanasi utilizing a fitting survey and appropriate measurable instruments. India is moving quick to rise as perhaps the most grounded economy on the planet by 2020. And yet, according to Dorothea Schmidt of the International Labor Organization (ILO) business pattern group, around $34.3 \%$ of the Indian populace are as yet living beneath the benchmark of \$1/day set by the United Nations Development Program (UNDP). Perhaps the most ideal approaches to take care of the issue of neediness in creating nations like India is to advance Small Scale Industries (SSI). It can assume a fundamental job in salary conveyance, financial self-reliance and monetary inspiring. The Central just as State Governments in India are finding a way to advance enterprising exercises. One untested supposition in arrangement having is the effect of frame of mind. Mentality arrangement is exceptionally affected by the family foundation of a person just as his/her instructive foundation. Subsequently, this paper theorizes that a person's family foundation and instructive capability impacts his/her disposition towards business people and enterprise. This speculation was tried on in

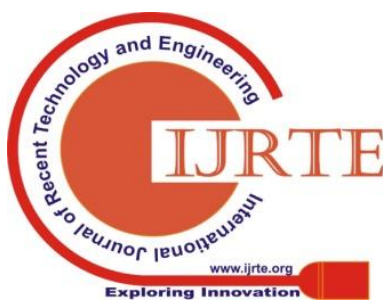


excess of 100 respondents in Varanasi utilizing a proper poll and appropriate factual devices.

Lavanya (2014) in her investigation investigate that Indian economy is exceptionally reliant on provincial economy as $72.2 \%$ of the absolute populace lives in country zones where horticulture and partnered exercises are the significant wellsprings of pay. Provincial business is beginning of ventures in country territories. Business enterprise is an astute response to unravel the joblessness, relocation and to advance monetary and social improvement in rustic zones. The fortifying of the country towns will energize the protection of regular assets and improve the provincial economy. There exists a wide hole among country and urban zones as far as framework, market and monetary access and so forth. To decrease the aberrations, renewing the rustic economy can be accomplished by setting up enterprising endeavors in provincial zones. Rising rustic wages will have a multiplier impact by raising the interest for homestead and nonfarm items and administrations prompting development of work openings .Government of India has been consistently appointing expanding significance and backing for the advancement and development of provincial business enterprise. The deterrents for development of country business enterprise are proficiency, hazard avoidance, absence of talented work, less specialized skill, restricted access to fundamental administrations, absence of correspondence offices and so on. This paper gives a knowledge into the present situation of provincial business, points of interest, openings, challenges looked by the business visionary and foundations advancing rustic business enterprise and their job in creating and encouraging country endeavors.

\section{RESEARCH METHODOLOGY}

Entrepreneurial Development Program me trainees from District Industries Centre, Thiruvallur is taken for the study. There are 1000 trainees during the study period and it is the population of the study. District Industries Centre gives training to three different schemes, Self-help group, trainees under Prime Minister Rozgar Yojana (PMRY) and technically qualified persons. District industries center has a target of giving training to 150 self-help group members per year. Self-help group members are connected through Mahalir Thittam, in this NGO's are acting as facilitators helping District Industries Centre in collecting the list of members in Self Help group. District Industries Centre has collected technically qualified persons list from Employment exchange of Thiruvallur. Business people or unemployed who wish to avail loan and concession given under PMRY scheme must apply to District Industries Centre.

The applications received by District Industries Centre are scrutinized and qualified applications are selected for training. Out of 1000 trainees 300 trainees are member of self-help group, 300 trainees are through PMRY scheme and 400 are technically qualified persons. Out of the 1000 trainees $10 \%$ of the respondents are only covered in my study, 25 from self-help group, 35 from PMRY scheme and
40 technically qualified persons are taken for studying adopting stratified random sampling method, structured questionnaire was framed in order to know the factors influencing in attending training programme and their perception on the effectiveness of training programme. The final study was conducted by interviewing 10 trainees and analysis tools applicable for trend analysis method and bar diagram.

\section{RESULTS AND DISCUSSION}

Table - 1: Annual Income

\begin{tabular}{|c|c|c|c|}
\hline Sl. No. & Income & Total & Percentage \\
\hline 1 & Up to Rs. 25000 & 43 & 43.0 \\
\hline 2 & Rs.25001- Rs.50000 & 40 & 40.0 \\
\hline 3 & Rs.50001- Rs.75000 & 14 & 14.0 \\
\hline 4 & Above Rs. 75001 & 3 & 3.0 \\
\hline \multicolumn{2}{|c}{ Total } & 100 & 100.0 \\
\hline
\end{tabular}

Source: Primary Data

From the above table it is inferred that $43 \%$ of the respondents earn below Rs.25,000, 40\% of the respondents earn between Rs.25,001-Rs.50,000, and 3\% of the respondents earn above Rs.75,000 and it is clear that from the respondents maximum number belong to the category of below Rs.25,000 income level.

Table - 2: Overall Satisfaction

\begin{tabular}{|c|l|c|c|}
\hline Sl. No. & \multicolumn{1}{|c|}{ Satisfaction } & Total & Percentage \\
\hline 1 & Extremely Satisfied & 21 & 21.0 \\
\hline 2 & Satisfied & 65 & 65.0 \\
\hline 3 & Neither Satisfied nor Dissatisfied & 11 & 11.0 \\
\hline 4 & Dissatisfied & 2 & 2.0 \\
\hline 5 & Extremely Dissatisfied & 1 & 1.0 \\
\hline \multicolumn{2}{|c|}{ Total } & 100 & 100.0 \\
\hline
\end{tabular}

Source: Primary Data

From the above table it is clear that $21 \%$ of the respondents are highly satisfied with the session given in the training, $65 \%$ of the group are satisfied and $11 \%$ of the group stands in a neutral view about the training program. So it is found that maximum number of respondents from the group were satisfied with the program. 


\section{A. Analysis of Variance: Influence of Age and Its Impact on Various Factors of Training Evaluation}

Table - 3: ANOVA Age and Its Impact on Various Factors of Training Evaluation

\begin{tabular}{|c|c|c|c|c|c|c|}
\hline Factors & One way analysis & Sum of Square & Df & $\begin{array}{l}\text { Mean } \\
\text { Square }\end{array}$ & $\mathrm{F}$ & Sig. \\
\hline \multirow{3}{*}{ RELEVANCE TO SUBJECT } & Between Groups & 383.3318 & 3 & 127.7773 & 8.175929 & .000 \\
\hline & Within Groups & 7595.436 & 96 & 15.62847 & & \\
\hline & Total & 7978.767 & 99 & & & \\
\hline \multirow{3}{*}{$\begin{array}{l}\text { CONTENT OF } \\
\text { PROGRAMME }\end{array}$} & Between Groups & 391.5268 & 3 & 130.5089 & 11.1169 & .000 \\
\hline & Within Groups & 5717.227 & 97 & 11.73969 & & \\
\hline & Total & 6108.754 & 100 & & & \\
\hline \multirow{3}{*}{$\begin{array}{l}\text { PRESENTATION } \\
\text { TECHNIQUES }\end{array}$} & Between Groups & 368.7627 & 3 & 122.9209 & 5.560764 & 0.00093 \\
\hline & Within Groups & 10765.15 & 97 & 22.10503 & & \\
\hline & Total & 11133.91 & 100 & & & \\
\hline \multirow{3}{*}{ TRAINING MATERIALS } & Between Groups & 99.51553 & 3 & 33.17184 & 9.462424 & .000 \\
\hline & Within Groups & 1707.246 & 97 & 3.505639 & & \\
\hline & Total & 1806.762 & 100 & & & \\
\hline \multirow{3}{*}{ FACILITIES PROVIDED } & Between Groups & 394.0188 & 3 & 131.3396 & 8.634823 & .000 \\
\hline & Within Groups & 7407.492 & 97 & 15.21046 & & \\
\hline & Total & 7801.511 & 100 & & & \\
\hline \multirow{3}{*}{ TRAINER'S ROLE } & Between Groups & 598.2399 & 3 & 199.4133 & 14.67025 & .000 \\
\hline & Within Groups & 6619.809 & 97 & 13.59304 & & \\
\hline & Total & 7218.049 & 100 & & & \\
\hline
\end{tabular}

The above table reveals the impact of age on various factors of influence on training group members which gives the $\mathrm{F}$ value of the factors, relevance $(\mathrm{F}=8.175, \mathrm{P}=0.000)$, programme content $(\mathrm{F}=11.116, \mathrm{P}=0.000)$, method of presentation $(\mathrm{F}=5.560, \quad \mathrm{P}=0.00093)$, training material $(\mathrm{F}=9.462, \mathrm{P}=0.000)$, facilities provided $(\mathrm{F}=8.634, \mathrm{P}=0.000)$, trainer role $(\mathrm{F}=14.670, \mathrm{P}-0.000)$ and they do not differ significantly with respect of age at $5 \%$ level. As regards the programme content and method of presentation it is statistically significant among the different age groups. In similar way it is noted that regarding instructional materials and facilities there is significant difference among the different age group. Regarding the factor trainer role is statistically significant among different age groups. From this we can conclude that $\mathrm{H} 0$ can be rejected at $5 \%$ level. This shows that perception on various factors of training evaluation among age groups are not same.

\section{FINDINGS}

- $53 \%$ of the respondents are females.

- $52 \%$ of the respondents belong to married status.

- Majority of the respondents (34\%) are having higher secondary level education.

- Majority of the respondents to (52\%) level are unemployed at the time of attending EDP.

- No part time training program is conducted by DIC among 100 trainees who were taken as sample and no trainee attended any other training program other than the training provided by DIC.
- $67 \%$ of the respondents stated that the course the course content was useful and practicable.

- $49 \%$ of the respondents stated that the relevancy of the topics covered with the course material is fair.

- $69 \%$ of the respondents suggested distributing the course material during the program.

- The importance of training ranked by the respondents, aware of government rules and regulations ranked first, developing self confidence ranked second, developing business contact ranked third.

- $11 \%$ expressed that the trainers covered cash management, $30 \%$ expressed that the trainers covered production management, $18 \%$ expressed that the trainers covered inventory control management, $15 \%$ expressed that the trainers covered marketing and sales management, $8 \%$ expressed that the trainers covered personnel management and $18 \%$ expressed that the trainers covered general management.

\section{SUGGESTIONS}

- Entrepreneurial education should be given from the school level.

- Training program must be formulated in such a way that they really match the type and level of entrepreneurial moves to be achieved.

- More emphasis should be placed on behavioral training. Impact such as sensitivity training, communication and interpersonal skills,

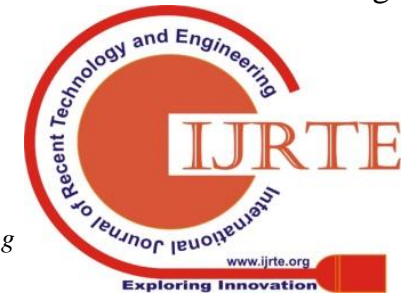


time management, etc should be adequately provided.

- A training program should aim at helping the trainees to identify their needs for further development of capabilities as entrepreneurs. Need based follow training should also be available.

- A training program should aim at strengthening inherent positive competencies.

- Finally duration of the training period should be increased wherever necessary.

\section{CONCLUSION}

Entrepreneurial development is the only way to tackle unemployment problems and to use to untapped human resources. Development without a proper training is impossible; Entrepreneurship is the process of increasing knowledge and skills of an entrepreneur to do entrepreneurial activity. It must motivate the entrepreneurial spirit of the trainees; we need innovative entrepreneurs then initiative entrepreneurs. So, institution involved in this process, think it seriously and do evaluate the existing system, its strength and weakness and reengineer the existing system to create innovative entrepreneurs. The solution lies in developing positive lineage between education and entrepreneurial development.

\section{REFERENCES}

1. Agarwal, K. K., \& Upadhyay, R. K. (2009). Attitude of youth towards entrepreneurship: A case study of Varanasi. IUP Journal of Entrepreneurship Development, 6(2), 49.

2. Cardon, M. S., Wincent, J., Singh, J., \& Drnovsek, M. (2005, August). Entrepreneurial Passion: The Nature of Emotions in Entrepreneurship. In Academy of Management Proceedings (Vol. 2005, No. 1, pp. G1-G6). Briarcliff Manor, NY 10510: Academy of Management.

3. Devi, R. U. (2013). An Impact Study of Micro Finance System on the Entrepreneurial Development of Andhra Pradesh, India. International Journal of Innovative Research and Development (ISSN 2278-0211), 2(4), 656-689.

4. Lavanya, S. M., Hemalatha, S., \& Indumathi, V. M. (2014). Perspectives of rural entrepreneurship in India. Journal of Management Research, 3(1), 95-100.

\section{AUTHOR PROFILE}

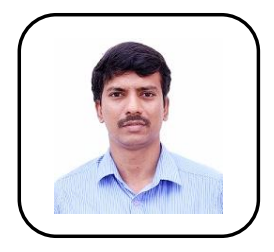

Dr. J. Johnson Pandian, is the Head of the Department of Commerce in K.C.S.Kasi Nadar College of Arts and Science,Chennai,Tamilnadu. He has received his Doctor of Philosophy in Commerce from Manonmanium Sundaranar University,Tirunelveli.He has published various papers in International Journals.His main Research Interests are Leadership Style, Organisational Culture,Social Entrepreneurship, Entrepreneurship Training,E-Banking and Mobile Commerce.He has participated in ICT Academy, Bridge course. 